\title{
28 Research Square \\ Boosting DLG2 expression could be one way to treat childhood cancer
}

Simon Keane

Sophie Ameen

Angelica Lindlöf

Katarina Ejeskär

\section{Video Byte}

Keywords: discs large homolog 2, DLG2, DLG2 expression, childhood cancer, neuroblastoma, tumor, early development, chromosome 11, DNA, Cell Communication and Signaling

Posted Date: June 23rd, 2020

DOI: https://doi.org/10.21203/rs.3.rs-37688/v1

License: (c) (i) This work is licensed under a Creative Commons Attribution 4.0 International License.

Read Full License 


\section{Abstract}

Neuroblastoma is a childhood tumor that forms in the neural crest during early development. While treatment has remained elusive, scientists do know that a partially deleted chromosome 11 contributes to one of the most aggressive forms of neuroblastoma. Here, researchers now say, lies an important gene whose absence gives rise to runaway tumor cell growth. That gene is discs large homolog 2, or DLG2. DLG2 and other genes in its family play important roles in cell structure and growth. DLG2 gene transfection experiments slowed the growth of neuroblastoma cells, whereas silencing DLG2 promoted neuroblastoma growth. A closer look revealed that low DLG2 expression fast-tracks cells through the growth phase of the cell cycle, bypassing a critical checkpoint designed to catch faulty DNA. A review of real-world patient data showed that low DLG2 expression is in fact correlated with poor survival in patients with neuroblastoma. Understanding how DLG2 expression might be enhanced early in life could lead to new treatment options for cancer patients. 